Article

\title{
Media Coverage and Perceived Policy Influence of Environmental Actors: Good Strategy or Pyrrhic Victory?
}

\author{
Adam C. Howe ${ }^{1, *}$, Mark C. J. Stoddart ${ }^{2}$ and David B. Tindall ${ }^{1}$ \\ ${ }^{1}$ Department of Sociology, University of British Columbia, Vancouver, V6T 1Z4, Canada; \\ E-Mails: adam.howe@mail.ubc.ca (A.C.H.), tindall@mail.ubc.ca (D.B.T.) \\ 2 Department of Sociology, Memorial University of Newfoundland, St. John's, A1C 5S7, Canada; E-Mail: mstoddart@mun.ca \\ * Corresponding author
}

Submitted: 30 October 2019 | Accepted: 29 February 2020 | Published: 2 June 2020

\begin{abstract}
In this article we analyze how media coverage for environmental actors (individual environmental activists and environmental movement organizations) is associated with their perceived policy influence in Canadian climate change policy networks. We conceptualize media coverage as the total number of media mentions an actor received in Canada's two main national newspapers - the Globe and Mail and National Post. We conceptualize perceived policy influence as the total number of times an actor was nominated by other actors in a policy network as being perceived to be influential in domestic climate change policy making in Canada. Literature from the field of social movements, agenda setting, and policy networks suggests that environmental actors who garner more media coverage should be perceived as more influential in policy networks than actors who garner less coverage. We assess support for this main hypothesis in two ways. First, we analyze how actor attributes (such as the type of actor) are associated with the amount of media coverage an actor receives. Second, we evaluate whether being an environmental actor shapes the association between media coverage and perceived policy influence. We find a negative association between media coverage and perceived policy influence for individual activists, but not for environmental movement organizations. This case raises fundamental theoretical questions about the nature of relations between media and policy spheres, and the efficacy of media for signaling and mobilizing policy influence.
\end{abstract}

\section{Keywords}

climate change; discourse networks; environment; media coverage; policy networks; social movements

Issue

This article is part of the issue "Policy Debates and Discourse Network Analysis" edited by Philip Leifeld (University of Essex, UK).

(C) 2020 by the authors; licensee Cogitatio (Lisbon, Portugal). This article is licensed under a Creative Commons Attribution 4.0 International License (CC BY).

\section{Introduction}

Research on the relationship of media coverage to policy influence historically tends to assume a symmetry between mediated political communication and policy influence/power (Russell, Dwidar, \& Jones, 2016; van Aelst, 2014). Previous analyses of the media-policy link specific to climate policy tend to focus either on influence within policy networks or visibility within media networks in isolation and draw inferences about how the two spheres are related based on a set of theoretical assumptions (Stoddart, Ylä-Anttila, \& Tindall, 2017). Herein we move beyond theoretical assumptions by empirically examining the association between climate change related media coverage of environmental activists and environmental non-governmental organizations (ENGOs), and the influence these actors are perceived as having in a climate change policy network.

With respect to policy influence, news media are linked to public policy in two important ways. First, news media provide the backdrop for contests between various conflicting interpretive frameworks or 'framings' of issues such as climate change, mobilized by interested constituencies (Benford \& Snow, 2000; Leifeld, 2017). 
Second, public policy is partly made through the influence that interested constituencies exert on policy makers through news media coverage (van Aelst, 2014; Vliegenthart, Walgrave, Wouters, et al., 2016). These enactments are shaped by a constellation of factors including journalistic norms and practices, the strategies and mobilization campaigns used by activists, industry and trade, and the particular types of overarching formal political processes/opportunity structures at play (Hutchins \& Lester, 2015; Leifeld, 2017; Meyer \& Minkoff, 2004).

Literature on the media-policy link from the fields of agenda setting (van Aelst, 2014; Vliegenthart, Walgrave, Wouters, et al., 2016; Walgrave \& Vliegenthart, 2012), policy networks (Kukkonen et al., 2018), and social movements (Gamson, 2007; Malinick, Tindall, \& Diani, 2013; Meyer \& Minkoff, 2004) suggests actors who garner more media coverage should be perceived as more influential in the policy sphere compared to those who garner less. Moreover, environmental actors have "stronger incentives to get media coverage than industry actors in order to reach bystander publics and put pressure on governments" (Stoddart, Tindall, Smith, \& Haluza-Delay, 2017, p. 386).

However, research on the Canadian media and policy spheres suggests that even if environmental actors are more prevalent in media coverage, this media presence may not always be positively associated with policy influence and outcomes. For example, recently in Canada environmental actors are more prevalent than industry actors in climate change related media coverage. At the same time, the interests of environmentalists are rarely reflected in climate policy, while those of industry often are (Carroll, 2018; Stoddart et al., 2017).

Building on this observation we analyze how media coverage of environmental actors is associated with their perceived policy influence. We find that for individual activists (those not acting on behalf of any formal organization), more media coverage is associated with less perceived policy influence, while for environmental organizations there is a small but significant positive association between media coverage and perceived policy influence. We use interview data to expand on our findings in our discussion.

This case raises fundamental theoretical questions about how sociopolitical reality is enacted, shaped and received through media, about the nature of relations between media and policy spheres, and about whetherfor activists-media success is a Pyrrhic victory (a victory that ironically leaves the victor damaged to such an extent that it is tantamount to a defeat) in terms of policy influence.

\section{Literature Review}

\subsection{Influence}

Political influence is a complex social phenomenon that can be difficult to measure in a meaningful way in terms of direct impacts on policy outcomes. Moreover, social influence may be conceived of and operationalized in a number of ways. One possibility is to approach influence as an objective, outcome-based measure to study whether an actor objectively has had an influence over other actors. For example, Vliegenthart, Walgrave, Wouters, et al. (2016) examine how media coverage of protest impacts question periods in European parliaments (an outcome measure of influence). They find that although media coverage of issues generally results in questions in parliament pertaining to these issues (evidence of a positive outcome of influence for activists), this is an indirect effect mediated through the broader issue agenda of mass media, which in turn is moderated by national political institutions.

Another approach common in network analyses conceives of social influence structurally, in terms of network centrality (the sum of all incoming and outgoing network ties an actor has) or structural equivalence (two actors sharing a similar pattern of network ties to other actors; Knoke \& Yang, 2008). For example, Heaney (2014) treats perceived influence as an outcome of actors' structural location across multiple intersecting networks of communication, policy issue overlap, and coalition overlap among policy network actors. Heaney finds that playing a brokerage role in communication networks is particularly important to perceived influence, but this cannot be clearly separated from the effects of issue overlap or coalition overlap networks.

By contrast, Fischer and Sciarini (2015) gauge how perceived influence (or 'reputational power') relates to political outcomes and whether policy network actors' understanding of the reputational power of others is accurate. They find that policy network actors' assessments of each other's reputational power are generally accurate, though there may be perception bias whereby the perceived influence of closer allies is overstated. Finally, Ingold and Leifeld (2016) examine several German and Swiss policy domains and argue that perceived influence (or 'influence reputation') is a function both of the authority derived from institutionally-defined roles, as well as by actors' structural locations in social networks.

These network studies of influence use exponential random graph models to simultaneously analyze the multiple interdependent factors that contribute to the perceived influence of policy network actors (for a good overview of this approach see Lusher, Koskinen, \& Robins, 2013). At the same time, these studies all focus on how perceived influence is shaped by social dynamics that are primarily endogenous to policy networks themselves, rather than focusing on how perceived influence can be shaped by external factors, such as media coverage.

We take neither of these approaches. We conceive of social influence social-psychologically, as a subjective evaluation (Gartrell, 1987) that actors make about other actors (see Heaney \& Lorenz, 2013, pp. 260-261, for a good summary of this approach). This approach in- 
volves directly asking actors to subjectively evaluate the influence of other actors. Heaney and Lorenz (2013) assert that "although any one respondent is likely to have an incomplete view of the field, [previous research suggests] respondents collectively are expected to provide a reasonably accurate rating of the levels of group influence" (p. 260).

While the network studies outlined above also use a subjective measure of perceived influence, our analysis offers an important addition to understanding perceived influence within policy networks. Rather than focussing on disentangling endogenous network processes, we explicitly examine an empirical correlation between media coverage and perceived influence in a policy network. This requires understanding how media and public policy are related.

\subsection{Media and Public Policy}

Generally, research related to media and policy falls into two streams. The first is political communication, which tends to focus on how media coverage impacts public opinion and the government's political agenda. The second is political science, which tends to focus on how media functions as an information exchange for policy actors, and how media coverage of particular issues can partly shape the political agenda (see Russell et al., 2016; van Aelst, 2014). Notably, there is little integration of the two streams (cf. Russell et al., 2016, p. 9), and both bodies of literature tend to use a set of assumptions based on linear/symmetrical relationships between media and policy (Russell et al., 2016; van Aelst, 2014). We depart from this tradition by employing the policy network and discourse network analytical frameworks.

Policy network analysis seeks to uncover the actors that are influential in policymaking and the interrelations that exist between them (Knoke, 1990; Ylä-Anttila et al., 2018). A policy network is a specific kind of social network, which can be generally defined as a set of political actors embedded within a set of structured, yet dynamic interrelations called network ties (Borgatti \& Halgin, 2011). Policy network actors socially interact on the basis of particular policy issues (Leifeld, 2017; Tindall, Stoddart, \& Callison, 2018; Ylä-Anttila et al., 2018). Actors include "government representatives, but also opposition parties, businesses, social movements, think-tanks, and scientists" (Stoddart et al., 2017, p. 389).

We also integrate a media discourse network perspective into our analysis. Discourse networks are constituted by political discourses, which are "verbal interactions between political actors about a given policy" (Leifeld, 2017, p. 302). They involve political actorsincluding politicians, environmentalists, scientists, think tanks, business leaders, NGOs, and others-making public statements about their policy beliefs, goals, and preferences (Leifeld, 2017). Some such actors are those involved in social movements.

\subsection{Social Movements and Media Coverage}

Studies of media coverage of social movements suggest activists seek media coverage in order to build up reputation, enter into policy debates, impact public policy, and exert influence over policymaking (Kukkonen et al., 2018; Malinick et al., 2013; Wilkes, Corrigall-Brown, \& Myers, 2010). Social movements engage in issue framing to try to reshape the frameworks people use to interpret how political issues impact their daily reality (Benford \& Snow, 2000; Snow, Rochford, Worden, \& Benford, 1986). This potentially influences bystanders to identify with the position of activists, while also encouraging people to mobilize (Snow et al., 1986).

For example, Stoddart, Smith, and Tindall (2016) found activists used the COP15 climate meeting in Copenhagen as a 'political opportunity' (Meyer \& Minkoff, 2004) to intervene in international media narratives and re-frame Canada's international reputation as a climate leader. Activists drew international attention to Canada's poor climate change performance, generating public awareness and political pressure (Stoddart et al., 2016). This demonstrates that environmental groups are able to act as "key organizational actors" (Stoddart et al., 2016 , p. 260) who play a role in structuring national and international news media discourse, and "articulate substantive claims" (Stoddart et al., 2016, p. 260) toward other political actors.

News media remain a key "field of engagement among a range of actors with a stake in climate change policy debate" (Stoddart et al., 2017, p. 386). The link between climate change and media has been extensively studied since about the mid 1990s, both within and across multiple societies, and especially in Europe and North America (Tindall et al., 2018). The type and amount of climate change news coverage differs substantially across countries (Boykoff, 2011). Over the last two decades the extent of media coverage of climate change has fluctuated, rising in concert with major media events such as COP meetings and the release of the Intergovernmental Panel on Climate Change (IPCC) and other reports, subsiding in the trough between (Boykoff, 2011; Broadbent et al., 2016). More recently, world media attention to climate change has been steadily rising (Boykoff, Katzung, \& Nacu-Schmidt, 2019).

Coverage in Canada is cyclical and event-driven. Between 1997 and 2010, coverage of climate change in Canada's two major national newspapers-the Globe and Mail and National Post-rose to a peak alongside the release of the fourth IPCC report and the Nobel Peace Prize being awarded to the IPCC and to Al Gore, and declined thereafter (Stoddart, Haluza-DeLay, \& Tindall, 2016). As of August 2019, coverage in Canada is up by about 38\% compared to August 2018 (Boykoff et al., 2019). Canadian coverage is increasingly oriented toward policy debates and discussion about proposed solutions to climate change (Stoddart \& Tindall, 2015; Young \& Dugas, 2011). 
In this analysis we are interested in whether, for environmental actors (individual activists and ENGOs), media coverage like that outlined above is positively associated with perceived policy influence. We examine the empirical correlation between media coverage of these environmental actors and the extent to which other policy actors subjectively perceived environmental actors as being influential in climate change policy making. Based on the literature above, we propose two main hypotheses.

\subsection{Hypotheses}

The literature outlined above suggests that environmental actors are incentivized to garner media attention, and that those who have more media coverage should be perceived as more influential by policy actors compared to actors who have less media coverage. However, regarding the second assertion, research on the Canadian media and policy spheres suggest the opposite may be true for individual environmental activists. To assess these claims, we test the following hypotheses:

$\mathrm{H1}$ : Being an environmental actor (either individual activist or environmental organization) is positively associated with media coverage.

$\mathrm{H} 2$ : Being an environmental actor (either individual activist or environmental organization) mediates the media coverage-perceived influence association, such that media coverage is negatively associated with perceived policy influence.

For a variety of reasons, media coverage may not always translate into perceived policy influence. What appears in the media is influenced by processes (such as journalistic norms) that operate beyond the importance of particular policy arguments, or the extent to which they appear compelling (Boykoff \& Boykoff, 2007; Callison, 2014). Also, debates in media may not accurately capture the "complexities of social interaction that occur within policy networks" (Stoddart et al., 2017, p. 387). Moreover, key policy actors may vary in their "need and ability to get media coverage" (Stoddart et al., 2017, p. 387). For example, influential actors may engage in 'strategic invisibility' (Lester \& Hutchins, 2012), withdrawing from public communication about environmental issues to avoid negative media coverage. Therefore, a positive association between media coverage and perceived policy influence should not be treated as axiomatic but rather as an empirical question. We now turn to a discussion of our data and methods.

\section{Methods}

\subsection{Data}

The data were gathered as part of the larger COMPON (Comparing Climate Change Policy Networks) project, which involved a discourse network analysis (Leifeld, 2017) of print news coverage of climate change in Canada, and interviews with/surveys completed by Canadian climate change policy actors. The media discourse data used here focuses on articles $(N=1,140)$ from Canada's two main national newspapers (Globe and Mail and National Post) during the period between June 2006 to June 2010. This period was chosen because it encompasses critical events including the Copenhagen COP meetings, which inspired contention and mobilization, and thus media coverage. These articles were analyzed using Discourse Network Analyzer (Leifeld, 2015), to identify actor agreement or disagreement across a range of concept statements pertaining to climate change governance in Canada. This enabled us to generate a detailed event list used to derive our media coverage variable.

In the interview and survey phase of the project, 77 respondents were interviewed beginning in February 2015, and 44 respondents completed online surveys between June 15th, 2015 and October 13th, 2016. The sample was designed to be representative of actors involved in climate change policy making in Canada. Pertinent actor types represented in the sampling frame included politicians, government bureaucrats, environmentalists, scientists, think tanks, business leaders, NGOs, and others.

The survey included five sections asking respondents about their network behaviors with respect to a list of network 'targets' (policy actors) that were systematically identified by the Principle Investigator of the original COMPON project. All of the organizations associated with survey respondents also appeared as targets in the survey. There are 171 targets in total, representing the range of policy-relevant actors. Our analysis is based on these 171 target actors. The survey question we focus on herein asked respondents to indicate who out of the 171 target actors they perceived to be influential in domestic climate change policy.

\subsection{Measures}

Descriptive statistics for our main and control variables are outlined in Table 1 . We conceptualize media coverage as the total number of media mentions an actor received in Canada's two main national newspapers - the Globe and Mail and National Post-over the duration of our study. We conceptualize perceived policy influence as the total number of times an actor was nominated by all other actors in a policy network as being perceived to be influential in domestic climate change policy making in Canada. These represent 'media coverage' and 'policy influence' respectively in the analyses below.

Our main independent variable is actor type, summarized in Table 2. Each survey target was assigned one of eight possible actor 'types' based on some key dimensions such as the sector they were located in (for e.g., civil society, academia, government, business, etc.), and the type of activity they undertook (for e.g., ac- 
Table 1. Descriptive statistics for non-categorical variables $(N=171)$.

\begin{tabular}{|c|c|c|c|c|}
\hline Variable & Mean & S.D. & Min & Max \\
\hline \multicolumn{5}{|l|}{ Dependent variables } \\
\hline Perceived influence & 6.46 & 6.24 & 0 & 23 \\
\hline Media coverage & 7.04 & 12.16 & 0 & 78 \\
\hline \multicolumn{5}{|l|}{ Interaction terms } \\
\hline Activist $\mathrm{X}$ media mentions & 0.18 & 1.38 & 0 & 17 \\
\hline ENGO X media mentions & 0.82 & 3.69 & 0 & 29 \\
\hline \multicolumn{5}{|l|}{ Control variables } \\
\hline$\%$ Agree w/business & $8.90 \%$ & $19.81 \%$ & $0 \%$ & $100 \%$ \\
\hline$\%$ Agree w/government & $9.48 \%$ & $17.16 \%$ & $0 \%$ & $100 \%$ \\
\hline$\%$ Not in business/government & $50.30 \%$ & $41.10 \%$ & $0 \%$ & $100 \%$ \\
\hline
\end{tabular}

tivism/advocacy, research, governing, business, etc.).

Each actor type is modelled as a binary variable that equals 1 if the target matches that type, and 0 if not. For example, an environmental organization target would have a value of 1 for the 'ENGO' type variable, and 0 for all other type variables. We excluded the government type variable, which acts as our referent type. It is important to include government actors in our analysis because they are a key part of the media/policy link (Vliegenthart, Walgrave, Baumgartner, et al., 2016).

Preliminary analysis indicated a potential 'crossover interaction' (Baron \& Kenny, 1986, p. 1174) between media coverage and perceived policy influence for individual activists and environmental organizations. Therefore, in our final model we interact media coverage with being an ENGO and with being an individual activist. These interaction terms are summarized in Table 1 as well. These are included to assess the extent to which being an individual activist or environmental organization shapes the correlation between media coverage and perceived policy influence. This speaks directly to our main hypotheses related to policy influence.

We include variables to control for the percentage of an actor's media coverage that aligns with the same themes associated with coverage of business and government actors. We also include a variable for the percentage of an actor's coverage that is unrelated to either business or government coverage.
Finally, we include two further dichotomous variables-one controlling for whether actors are federal/national versus sub-national, and one controlling for whether actors are organizations versus individuals. While we do include individual activists as an actor type, there are other actors in the analysis who are individuals (for example, media actors).

\section{Analytic Strategy}

We use negative binomial Poisson regression, because our main dependent variables are count measures that follow the Poisson distribution and exhibit some over-dispersion (Cameron \& Trivedi, 2013, pp. 80-85). Preliminary analysis showed that neither zero-inflated nor zero-truncated regression were a better a fit to the data (for details on model selection see Cameron \& Trivedi, 2013; Wilson, 2015). We use Huber-White robust standard errors to account for unequal error variance across observations. This is a common problem with generalized linear regression models, including negative binomial regression. Huber-White robust standard errors provide asymptotically correct standard errors for models where the variance of residuals is unequal across observations (Cameron \& Trivedi, 2013, pp. 84-85).

The first model uses media coverage as the dependent variable to assess the factors associated with media coverage that an actor receives. The second model is the

Table 2. Descriptive statistics for actor type variable.

\begin{tabular}{lrr}
\hline Actor type & Frequency & $\%$ \\
\hline Government (reference cat.) & 45 & $26.32 \%$ \\
Business & 30 & $17.54 \%$ \\
Research & 27 & $15.79 \%$ \\
ENGO & 24 & $14.04 \%$ \\
Media & 21 & $12.28 \%$ \\
Activist & 12 & $7.02 \%$ \\
Think Tank & 6 & $3.51 \%$ \\
NGO & 6 & $3.51 \%$ \\
Total & 171 & $100.00 \%$ \\
\hline
\end{tabular}


primary model, which regresses media coverage on perceived policy influence. To disentangle the link between media coverage and perceived policy influence for individual activists and environmental organizations, we include our two interaction terms in this model. We now turn to our results.

\section{Results}

The results of our first model related to media coverage are presented in Table 3. All else being equal, actors perceived as more influential are associated with more media coverage. Organizations receive less media coverage compared to individuals, and federal/national actors receive more coverage compared to non-federal/national (regional) actors.

Looking at our actor type variables (relevant to $\mathrm{H} 1$ ) reveals that compared to government actors, business actors and individual activists receive less media coverage whereas there is no significant difference for environmental organizations, or any other actor type.

The results of our second analysis related to policy influence are presented in Table 4. Higher values of media coverage are significantly associated with higher num- bers of nominations as being perceived as influential in policy networks $(p<.05)$. The same holds for being a federal/national actor compared to non-federal/national (regional) actors $(p<.01)$.

The higher the percentage of an actor's media coverage that aligns with the same themes associated with coverage of business, the more influential they are perceived to be $(p<0.10)$. There seems to be no significant association between perceived policy influence, and either (1) the percentage of an actor's coverage that aligns with government, or (2) the percentage of an actor's coverage that is not related to business or government themes.

Looking at our actor type variables suggests that, compared to being a government actor, being a business, research, or NGO actor is associated with fewer nominations of being perceived as influential.

Turning to the interaction terms (relevant to $\mathrm{H} 2$ ) we find that for individual activists the association between media coverage and perceived policy influence is significantly negative $(p<.001)$, whereas for environmental organizations the association is significantly positive $(p<.001)$. For individual activists, more media mentions are associated with fewer perceived policy in-

Table 3. Negative binomial Poisson regression of perceived policy influence on media coverage, with robust standard errors.

\begin{tabular}{|c|c|c|}
\hline Media coverage & Model 1 & Model 2 \\
\hline Perceived influence & $\begin{array}{l}0.093^{* * *} \\
(0.014)\end{array}$ & $\begin{array}{l}0.093^{* * *} \\
(0.014)\end{array}$ \\
\hline \multicolumn{3}{|l|}{ Attributes $(1 / 0)$} \\
\hline Organization ( $0=$ individual) & $\begin{array}{c}-0.467 \\
(0.241)\end{array}$ & $\begin{array}{c}-0.569 * \\
(0.289)\end{array}$ \\
\hline Federal/National ( $0=$ regional) & $\begin{array}{c}0.442 * \\
(0.205)\end{array}$ & $\begin{array}{l}0.623^{* *} \\
(0.214)\end{array}$ \\
\hline \multicolumn{3}{|l|}{ Actor type (1/0) } \\
\hline Activist & & $\begin{array}{c}-1.260 * \\
(0.615)\end{array}$ \\
\hline ENGO & & $\begin{array}{c}-0.267 \\
(0.272)\end{array}$ \\
\hline Business & & $\begin{array}{c}-0.633^{*} \\
(0.267)\end{array}$ \\
\hline Media & & $\begin{array}{c}-0.254 \\
(0.325)\end{array}$ \\
\hline Research & & $\begin{array}{c}0.399 \\
(0.313)\end{array}$ \\
\hline NGO & & $\begin{array}{c}-0.273 \\
(0.708)\end{array}$ \\
\hline Think Tank & & $\begin{array}{c}-0.568 \\
(0.330)\end{array}$ \\
\hline Constant & $\begin{array}{l}1.259 * * * \\
(0.252)\end{array}$ & $\begin{array}{l}1.434^{* * *} \\
(0.328)\end{array}$ \\
\hline Pseudo $\mathrm{R}^{2}$ & 0.045 & 0.059 \\
\hline $\mathrm{BIC}$ & -584.082 & -569.058 \\
\hline$N$ & 171 & 171 \\
\hline
\end{tabular}

Notes: $* p<.05, * * p<.01, * * * p<.001$ 
Table 4. Negative binomial Poisson regression of media coverage on perceived policy influence, with robust standard errors.

\begin{tabular}{|c|c|c|c|c|}
\hline Perceived policy influence & Model 1 & Model 2 & Model 3 & Model 4 \\
\hline Media coverage & $\begin{array}{l}0.025 * * * \\
(0.006)\end{array}$ & $\begin{array}{l}0.020 * * * \\
(0.006)\end{array}$ & $\begin{array}{l}0.015^{* *} \\
(0.006)\end{array}$ & $\begin{array}{c}0.011^{*} \\
(0.005)\end{array}$ \\
\hline \multicolumn{5}{|l|}{ Attributes (1/0) } \\
\hline Organization ( $0=$ individual) & $\begin{array}{c}0.149 \\
(0.174)\end{array}$ & $\begin{array}{c}0.121 \\
(0.163)\end{array}$ & $\begin{array}{c}0.030 \\
(0.207)\end{array}$ & $\begin{array}{c}0.019 \\
(0.205)\end{array}$ \\
\hline Federal/National ( $0=$ regional) & $\begin{array}{l}0.518^{* * *} \\
(0.139)\end{array}$ & $\begin{array}{l}0.624^{* * *} \\
(0.145)\end{array}$ & $\begin{array}{l}0.505^{* *} \\
(0.163)\end{array}$ & $\begin{array}{l}0.545^{* *} \\
(0.163)\end{array}$ \\
\hline \multicolumn{5}{|l|}{ Coverage type } \\
\hline$\%$ Agree $\mathrm{w} /$ business & & $\begin{array}{c}0.719^{\dagger} \\
(0.390)\end{array}$ & $\begin{array}{c}1.202 * \\
(0.492)\end{array}$ & $\begin{array}{c}1.268^{\dagger} \\
(0.500)\end{array}$ \\
\hline$\%$ Agree w/government & & $\begin{array}{c}0.776^{\dagger} \\
(0.431)\end{array}$ & $\begin{array}{c}0.416 \\
(0.441)\end{array}$ & $\begin{array}{c}0.453 \\
(0.445)\end{array}$ \\
\hline$\%$ Not in business/government & & $\begin{array}{c}0.007 \\
(0.193)\end{array}$ & $\begin{array}{c}0.212 \\
(0.201)\end{array}$ & $\begin{array}{c}0.203 \\
(0.201)\end{array}$ \\
\hline \multicolumn{5}{|l|}{ Actor type (1/0) } \\
\hline Activist & & & $\begin{array}{c}-0.101 \\
(0.347)\end{array}$ & $\begin{array}{c}0.113 \\
(0.360)\end{array}$ \\
\hline ENGO & & & $\begin{array}{c}0.030 \\
(0.212)\end{array}$ & $\begin{array}{c}-0.298 \\
(0.269)\end{array}$ \\
\hline Business & & & $\begin{array}{c}-0.563^{*} \\
(0.260)\end{array}$ & $\begin{array}{c}-0.599 * \\
(0.261)\end{array}$ \\
\hline Media & & & $\begin{array}{c}0.059 \\
(0.198)\end{array}$ & $\begin{array}{c}0.050 \\
(0.194)\end{array}$ \\
\hline Research & & & $\begin{array}{c}-0.923^{*} \\
(0.291)\end{array}$ & $\begin{array}{c}-0.917^{* *} \\
(0.293)\end{array}$ \\
\hline NGO & & & $\begin{array}{c}-0.921^{*} \\
(0.495)\end{array}$ & $\begin{array}{c}-0.925^{\dagger} \\
(0.494)\end{array}$ \\
\hline Think Tank & & & $\begin{array}{c}-0.050 \\
(0.354)\end{array}$ & $\begin{array}{c}-0.059 \\
(0.358)\end{array}$ \\
\hline \multicolumn{5}{|l|}{ Interactions } \\
\hline Activist $X$ media coverage & & & & $\begin{array}{c}-0.130 * * * \\
(0.033)\end{array}$ \\
\hline ENGO X media coverage & & & & $\begin{array}{l}0.044^{* * *} \\
(0.012)\end{array}$ \\
\hline Constant & $\begin{array}{l}1.316 * * * \\
(0.175)\end{array}$ & $\begin{array}{l}1.174 * * * \\
(0.200)\end{array}$ & $\begin{array}{l}1.423^{* * *} \\
(0.248)\end{array}$ & $\begin{array}{l}1.450 * * * \\
(0.247)\end{array}$ \\
\hline Pseudo $\mathrm{R}^{2}$ & 0.028 & 0.036 & 0.056 & 0.063 \\
\hline $\mathrm{BIC}$ & -681.579 & -672.492 & -651.802 & -646.420 \\
\hline N. Obs. & 171 & 171 & 171 & 171 \\
\hline
\end{tabular}

Notes: ${ }^{\dagger} \mathrm{p}<.10,{ }^{*} \mathrm{p}<.05,{ }^{* *} \mathrm{p}<.01,{ }^{* * *} \mathrm{p}<.001$.

fluence nominations. For environmental organizations, more media mentions are associated with more influence nominations.

Both of our hypotheses are partially supported by our results, and we have some interesting findings with respect to the association between media coverage and perceived policy influence for individual activists. To clarify our results and draw out important implications for theory and future research, we now turn to a discussion of these findings.

\section{Discussion}

\subsection{A Pyrrhic Victory}

Recall that the interaction terms in Table 4 represent a 'crossover interaction' (Baron \& Kenny, 1986, p. 1174). In our case, being an individual activist moderates the association between media coverage and perceived policy influence such that the association is negative. In contrast, this association is positive for environmental organizations. 
This moderation effect comes into play for actors who had at least eight media mentions. For reference, the average number of media mentions for individual activists in our data is about eight, and about nine for environmental organizations. We can use our regression model along with these averages to predict the total number of nominations of being influential that an individual activist, or an environmental organization, may receive. Using eight media mentions, activists are predicted to get four influence nominations while environmental organizations are predicted to get $10(p<.001)$.

To better illustrate this interaction, Figure 1 graphs adjusted predictions of number of nominations of being perceived as influential for individual activists and environmental organizations. To calculate these predictions, we set the variables for percent of an actor's media coverage related to business, government, and neither, to their mean values. We also assume that individual activists and environmental organizations are both federal-level actors (this is a more conservative assumption for activists, since many activists are not federal actors). Finally, we set the organization variable accordingly; for environmental organizations the variable equals 1 , whereas it equals 0 for individual activists.

When we consider environmental organizations, neither of our hypotheses is supported. Our results suggest that environmental organizations receive about the same amount of coverage as government actors (Table 3), and that higher numbers of media mentions are associated with more nominations as being perceived as influential (Table 4). When we consider individual activists, $\mathrm{H} 1$ is again not supported-individual activists receive less coverage than do environmental organizations (Table 3). However, for individual activists, $\mathrm{H} 2$ is supported-for individual activists, higher numbers of media mentions are associated with fewer nominations of perceived policy influence (Table 4). Thus, in certain contexts media coverage may actually be a Pyrrhic victory for individual activists.

In considering existing theoretical assumptions about the relationship between media visibility and perceived policy influence, our analysis suggests that there are other contextual factors-in our case, the type of actor under consideration-that play an important role in shaping this relationship. Our analysis demonstrates that theoretical assumptions of a positive association between media coverage and perceived policy influence need to be carefully examined. This symmetrical relation should not be assumed but evaluated case by case. Future research should seek to elaborate on the conditions wherein a positive or negative relation holds.

Recall from our earlier discussion that media coverage may not be associated with perceived policy influence due to a variety of factors-journalistic norms (Boykoff \& Boykoff, 2007; Callison, 2014), the complexities of policy networks not captured in mediated debates (Stoddart et al., 2017), and variations in policy actors' need for, and ability to garner media coverage (Stoddart et al., 2017).

In addition, there are many reasons why actors might be selected for media coverage beyond being perceived as influential by other policy actors. For example, policy networks can provide a kind of social capital, and media actors can be drawn into policy networks through this social capital structure to identify their news sources (Malinick et al., 2013). Journalists do tend to have established relationships with particular sources and rely on them due to considerations of time and accuracy, and the ability of sources to provide reliable, concise, and coherent responses. This is likely a part of the effect of perceived influence on media coverage and is currently being explored by the authors elsewhere. Nevertheless, we cautiously offer potential explanations of our key findings related to individual activists.

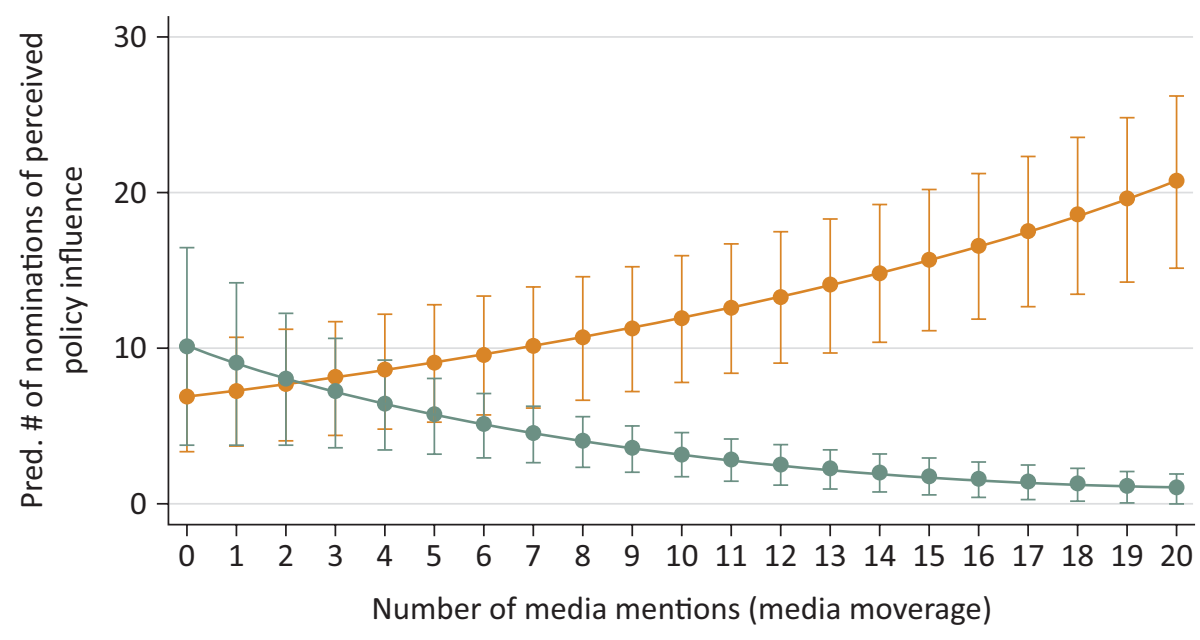

$\longrightarrow$ Environmental Organization $\longleftarrow$ Individual Activist

Figure 1. Adjusted predictions of perceived policy influence nominations based on number of media mentions, with $95 \%$ confidence intervals. 
One possibility is that there is some form of institutional legitimacy afforded to environmental organizations as a result of 'NGOization'-a process whereby grassroots groups and their networks "shift from rather loosely organized, horizontally dispersed, and broadly mobilized social movements to more professionalized, vertically structured NGOs" (Lang, 2013, p. 62). NGOs seek to "influence decision making by gaining some degree of insider status in institutions or in organizations that initiate, prepare, legislate, or execute policy change" (Lang, 2013, p. 22).

Moreover Lang (2013, p. 64) argues:

Emphasis is placed on organizational reproduction and on the cultivation of funding sources. It frequently results in increased recognition and insider status in NGOs' issue-specific policy circles. One effect might be the containment and reframing of more radical messages; another effect might be an orientation toward institutional advocacy and away from public displays of dissent.

By operating outside of (and in many ways overtly challenging) this institutional context, individual activists may have a legitimacy 'penalty' levied against them. This is consistent with literature on insider and outsider activist strategies (Fogarty, 2011; Grant, 2004), and with literature on the sociology of knowledge that shows organizational characteristics (such as funding) acting as a "common heuristic for judging credibility and broad political 'allegiances"' (McLevey, 2014, p. 55; see also Choudry \& Kapoor, 2013).

We can see the contours of these processes in our interview responses. When asked about the role of environmentalists in climate change politics, one prominent government actor explains how the use of radical messaging, displays of dissent, and challenging institutional legitimacy leads to a lack of perceived policy influence:

I have worked with some [NGOs] that are really very capable, like really smart and strategic, people who kind of look at it and figure out what is the best way for them to engage and make a difference and who they can influence and how to influence them. So, some of the most impressive people I know work in NGOs. But I have also met some people that are just kind of useless, frankly. I mean...some people...sit there and say "I do not agree with this process, I do not think industry should even be at this table. I do not think any standard that anyone has set was tough enough." But they did not really shape anything. Everybody in the room, including other NGOs, were like "duly noted" and then we went back to trying to reach an agreement. Right like if you did not want to participate, why are you here?

Another possibility involves the 'devil shift' (Sabatier, Hunter, \& McLaughlin, 1987) and 'angel shift' (Leach \&
Sabatier, 2005) phenomena. The devil shift is the tendency of political actors to underestimate their own political influence, while simultaneously overestimating the influence and malice of their opponents (Sabatier et al., 1987). In contrast the angel shift is the tendency for political actors to exalt themselves and their political partners (Leach \& Sabatier, 2005). These are social-psychological processes mediated through political discourse.

We see these processes in some of our interview responses. When asked about potential solutions to climate change in Canada, one activist reveals how the failure of political actors to take meaningful action makes them a more difficult obstacle to overcome, requiring more drastic action:

If you looked at it when it first started, I would tell you energy efficiency and incremental improvements are the best way to go about it because then you can achieve it without too many disruptions to the economy. That is no longer the case. Now we need to have disruptive action in order to make the most effective changes that we can as quickly as we can. So, in fact... what we have to do is becoming harder. And there is still not a recognition in politicians...that extreme things have to be done in order to avert the disaster that is awaiting us.

When asked about the current state of climate change politics in Canada, the same activist extolls the virtue of their own position in the face of opposition:

The politics of climate change in Canada are very negative.....t has been used as a tool by the present federal government to beat up on previous governments and to offend....So it has been a very bitter kind of battle....We have a strong desire to do the right thing but...if we are not prepared to cap our emissions we are not going to be able to achieve anything.

Moreover, the constellation of actors in the field of environmental policy also shapes how media coverage affects policy influence (van Aelst, 2014). Earlier we outlined how the Canadian environmental policy field is largely characterized by interlocking relations between industry and state actors (Carroll, 2018). It is also true that media coverage of sensational issues like the environment has a high likelihood of influencing the public and the policy agenda (see van Aelst, 2014, pp. 239-240).

When we consider this alongside our preliminary explanations and interview data outlined herein, it is reasonable to argue that there may be some push back-at least from industry and/or government actors-against individual environmental activists, whose main targets are industry and state actors and existing political institutions, and who are highly motivated to garner media coverage. In contrast, the more consensus-oriented strategies of environmental organizations could explain their relatively more influential position. Alternatively, individ- 
ual activists in more radical groups may be more prominent in media coverage, while those in more mainstream groups may be less (cf. Malinick et al., 2013).

While this is by no means an exhaustive exploration of possible explanations for our findings with respect to individual activists, these two explanations are plausible, supported by literature, and reflected in our interview data.

\subsection{Limitations}

We acknowledge that the relationship between media coverage and perceived policy influence is bidirectional. That is, media coverage may be associated with perceived policy influence, and being an influential policy actor may garner more media coverage. To fully explore this question requires analyzing longitudinal data. In an ideal research design, researchers could try to model how this relationship changes over time, how the introduction of new actors into a policy domain affect this relationship, or how different strategies used by actors shape this relationship. While these are important questions, they are outside the scope of our analysis.

First, our analysis is not longitudinal but crosssectional. We assert that although a longitudinal design is ordinarily considered a methodological improvement on a cross-sectional one, it still may not adequately address the question of bidirectionality. For example, consider the bidirectional inter-relations between the issue attention cycle and media coverage (Downs, 1972), or the many associations between media coverage, actor influence, and political opportunity structures. Moreover, cross-sectional methods can be quite robust. Recall that exponential random graph models-a cross-sectional method specifically designed to analyze network datahave proven successful at disentangling the complex network-based processes that shape influence in political networks (see Fischer \& Sciarini, 2015; Heaney, 2014; Ingold \& Leifeld, 2016).

Second, we are examining the correlation between media coverage and perceived policy influence. In terms of practicality, answering longitudinal questions is easier to do with media data than with network data, given access to actors and the resources required to gather network data. Nevertheless, our analysis is one of the first to empirically examine this correlation, the first we are aware of using Canadian data, and an important addition to extant literature on social influence in policy networks as well as literature on social movements and media.

A third limitation of our analysis involves our measure of perceived policy influence. We have evidence of an empirical correlation between media coverage and perceived policy influence and examine that herein. However, it may be argued that no single actor in our policy network has complete information about all other actors in our network, and that evaluations of influence could be shaped by personal relations between network actors (Heaney \& Lorenz, 2013).
We argue-in line with Heaney and Lorenz (2013)that our measure is valid for two main reasons. First, actors in our network are "uniquely knowledgeable of the inner workings" (Heaney \& Lorenz, 2013, p. 261) of climate change governance in Canada. This agrees with Fischer and Sciarini's (2015) findings outlined earlier that network actors' understanding of the reputational power of others is accurate. Second, our sample of policy actors was designed to be representative of the climate change policy domain in Canada and has very good coverage of the key actors involved in climate change governance in Canada. We will investigate other aspects of this relationship in future analyses.

Finally, our discourse network data precedes our policy network data by about five years. It is not clear whether or not this improves the validity of our analysis (by acting as an informal time lag), so readers should keep this in mind when considering our findings.

\section{Conclusion}

In this article we analyze how media coverage for individual environmental activists and environmental movement organizations is associated with their perceived policy influence in a climate change policy network. We find that media coverage may be a Pyrrhic victory for individual activists, for whom higher levels of media coverage do not correspond with higher levels of perceived policy influence. This raises fundamental theoretical questions about common symmetrical assumptions about the relationship between media coverage and policy influence (see Russell et al., 2016; Stoddart et al., 2017; van Aelst, 2014), and the efficacy of media for signaling and mobilizing policy influence.

Our findings demonstrate these assumptions are only partly correct and should not be assumed. Rather, the link between media and policy should be an empirical question, not an a priori assumption. The complex processes shaping media attention and policy influence may be similar but are also independent. They play out in different sociopolitical contexts and are shaped by different mechanisms. This highlights the importance of further research that bridges media analysis and policy network analysis in order to help us better understand how visibility, power/influence, and policy influence work across media spheres and policy networks.

Our study also addresses the "lack of connections between studies of the media and studies of public policy processes" (Russell et al., 2016, p. 2), and calls for research at the level of individual political actors, to help clarify mechanisms that explain "why and when political actors react to media coverage" (van Aelst, 2014, p. 234). Our findings suggest that in a context where government is increasingly hostile toward climate science and climate activism (such was the case in Canada during data collection for this project), media coverage of individual activists may lead policy network actors to perceive activists as less influential than environmental organizations. 
We put forth two potential explanations for these findings. The first is related to processes of NGOization and the various ways that political actors use heuristics to judge credibility and political allegiance. The second is related to the devil shift and angel shift phenomena. Both explanations are supported by literature and our interview data. Ultimately our goal is to provide empirical, substantive findings to improve our understanding of climate change governance, environmental activism, and the media-policy link. We will explore some of these explanations in future analyses, and the current analysis provides a good foundation for these, and other similar studies.

\section{Acknowledgments}

Jeffrey Broadbent, Randolph Haluza-Delay, Philip Leifeld, Keiichi Satoh, and participants of the October 2019 COMPON workshop at the University of Bern, Switzerland, provided valuable input throughout the development of this project. The authors would like to acknowledge the research assistance of Noelani Dubeta, Michelle Hay, Emily Maynard, and Georgia Piggot. Funding for this research was provided by the Social Sciences and Humanities Research Council of Canada. This article utilizes comparative research methods and data collection instruments collaboratively developed by the program on Comparing Climate Change Policy Networks (COMPON, http://compon.org) initiated and led by Jeffrey Broadbent, University of Minnesota, with Co-Principal Investigators Dana R. Fisher and Katsumi Matsumoto and funded by the US National Science Foundation [grant number BCS-08270069]. An earlier version of this article was presented at the October 2019 COMPON workshop at the University of Bern, Switzerland.

\section{Conflict of Interests}

The authors declare no conflict of interests.

\section{Supplementary Files}

Supplementary material for this article is available online in the format provided by the authors (unedited).

\section{References}

Baron, R. M., \& Kenny, D. A. (1986). The moderatormediator variable distinction in social psychological research: Conceptual, strategic, and statistical concerns. Journal of Personality and Social Psychology, 51(6), 1173-1182.

Benford, R. D., \& Snow, D. A. (2000). Framing processes and social movements: An overview and assessment. Annual Review of Sociology, 26, 611-639.

Borgatti, S. P., \& Halgin, D. S. (2011). On network theory. Organization Science, 22(5), 1168-1181.
Boykoff, M. T. (2011). Who speaks for the climate? Making sense of media reporting on climate change. Cambridge: Cambridge University Press.

Boykoff, M. T., \& Boykoff, J. M. (2007). Climate change and journalistic norms: A case-study of US massmedia coverage. Geoforum, 38(6), 1190-1204.

Boykoff, M. T., Katzung, J., \& Nacu-Schmidt, A. (2019). I am an environmentalist. Boulder, CO: Media and Climate Change Observatory, University of Colorado Boulder. Retrieved from https://ciresblogs.colorado. edu/prometheus/2019/09/04/mecco-monthlysummary-i-am-an-environmentalist

Broadbent, J., Sonnett, J., Botetzagias, I., Carson, M., Carvalho, A., Chien, Y. J., . . . Zhengyi, S. (2016). Conflicting climate change frames in a global field of media discourse. Socius: Sociological Research for a Dynamic World, 2. https://doi.org/10.1177/ 2378023116670660

Callison, C. (2014). How climate change comes to matter: The communal life of facts. Durham, NC: Duke University Press.

Cameron, A. C., \& Trivedi, P. K. (2013). Regression analysis of count data (2nd ed.). Cambridge: Cambridge University Press.

Carroll, W. K. (2018). Who owns Canada's fossil-fuel sector? Mapping the network of ownership. Vancouver: Canadian Centre for Policy Alternatives.

Choudry, A., \& Kapoor, D. (2013). Introduction. In A. Choudry \& D. Kapoor (Eds.), NGOization: Complicity, contradictions and prospects (pp. 1-23). New York, NY: Zed Books.

Downs, A. (1972). Up and down with ecology: The 'issueattention cycle.' The Public Interest, 28, 38-50.

Fischer, M., \& Sciarini, P. (2015). Unpacking reputational power: Intended and unintended determinants of the assessment of actors' power. Social Networks, 42, 60-71.

Fogarty, E. A. (2011). Nothing succeeds like access? NGO strategies towards multilateral institutions. Journal of Civil Society, 7(2), 207-227.

Gamson, W. A. (2007). Bystanders, public opinion, and the media. In D. A. Snow, S. A. Soule, \& H. Kriesi (Eds.), The Blackwell companion to social movements (pp. 242-261). Malden, MA: Blackwell Publishing.

Gartrell, C. D. (1987). Network approaches to social evaluation. Annual Review of Sociology, 13(1), 49-66.

Heaney, M. T. (2014). Multiplex networks and interest group influence reputation: An exponential random graph model. Social Networks, 36, 66-81.

Heaney, M. T., \& Lorenz, G. M. (2013). Coalition portfolios and interest group influence over the policy process. Interest Groups and Advocacy, 2(3), 251-277.

Hutchins, B., \& Lester, L. (2015). Theorizing the enactment of mediatized environmental conflict. International Communication Gazette, 77(4), 337-358.

Ingold, K., \& Leifeld, P. (2016). Structural and institutional determinants of influence reputation: A comparison of collaborative and adversarial policy networks in 
decision making and implementation. Journal of Public Administration Research and Theory, 26(1), 1-18.

Knoke, D. (1990). Political networks: The structural perspective. New York, NY: Cambridge University Press.

Knoke, D., \& Yang, S. (2008). Social network analysis (2nd ed.). Thousand Oaks, CA: Sage Publications.

Kukkonen, A., Ylä-Anttila, T., Swarnakar, P., Broadbent, J., Lahsen, M., \& Stoddart, M. C. J. (2018). International organizations, advocacy coalitions, and domestication of global norms: Debates on climate change in Canada, the US, Brazil, and India. Environmental Science and Policy, 81, 51z4-62.

Lang, S. (2013). The NGOization of civil cociety. In S. Lang (Ed.), NGOs, civil society, and the public sphere (pp. 60-96). Cambridge: Cambridge University Press.

Leach, W. D., \& Sabatier, P. A. (2005). To trust an adversary: Integrating rational and psychological models of collaborative policymaking. American Political Science Review, 99(4), 491-503.

Leifeld, P. (2015). Discourse Network Analyzer (DNA): A java-based software for qualitative data analysis with network export. Github. Retrieved from https:// github.com/leifeld/dna

Leifeld, P. (2017). Discourse network analysis: Policy debates as dynamic networks. In J. N. Victor, A. H. Montgomery, \& M. Lubell (Eds.), The Oxford handbook of political networks (pp. 301-326). Oxford: Oxford University Press.

Lester, L., \& Hutchins, B. (2012). The power of the unseen: Environmental conflict, the media and invisibility. Media, Culture \& Society, 34(7), 847-863.

Lusher, D., Koskinen, J., \& Robins, G. (Eds.). (2013). Exponential random graph models for social networks: Theory, methods and applications. New York, NY: Cambridge University Press.

Malinick, T. E., Tindall, D. B., \& Diani, M. (2013). Network centrality and social movement media coverage: A two-mode network analytic approach. Social Networks, 35(2), 148-158.

McLevey, J. (2014). Think tanks, funding, and the politics of policy knowledge in Canada. Canadian Review of Sociology, 51(1), 54-75.

Meyer, D. S., \& Minkoff, D. C. (2004). Conceptualizing political opportunity. Social Forces, 82(4), 1457-1492.

Russell, A., Dwidar, M., \& Jones, B. D. (2016). The mass media and the policy process. Oxford: Oxford University Press.

Sabatier, P. A., Hunter, S., \& McLaughlin, S. (1987). The devil shift: Perceptions and misperceptions of opponents. Western Political Quarterly, 40(3), 449-476.

Snow, D. A., Rochford, E. B., Worden, S. K., \& Benford, R. D. (1986). Frame alignment processes, micromobilization, and movement participation. American Sociological Review, 51(4), 464-481.

Stoddart, M. C. J., Haluza-DeLay, R., \& Tindall, D. B. (2016). Canadian news media coverage of climate change: Historical trajectories, dominant frames, and international comparisons. Society and Natural Re- sources, 29(2), 218-232.

Stoddart, M. C. J., Smith, J., \& Tindall, D. B. (2016). Blame Canada: Environmental movements, national media and Canada's reputation as a climate villain. In W. $\mathrm{K}$. Carroll \& K. Sarker (Eds.), A world to win: Contemporary social movements and counter-hegemony (pp. 250-266). Winnipeg: ARP Books.

Stoddart, M. C. J., \& Tindall, D. B. (2015). Canadian news media and the cultural dynamics of multilevel climate governance. Environmental Politics, 24(3), 401-422.

Stoddart, M. C. J., Tindall, D. B., Smith, J., \& HaluzaDelay, R. (2017). Media access and political efficacy in the eco-politics of climate change: Canadian national news and mediated policy networks. Environmental Communication, 11(3), 386-400.

Stoddart, M. C. J., Ylä-Anttila, T., \& Tindall, D. B. (2017). Media, politics, and climate change: The ASA Task Force report and beyond. Environmental Sociology, 3(4), 309-320.

Tindall, D. B., Stoddart, M. C. J., \& Callison, C. (2018). The relationships between climate change news coverage, policy debate, and societal decisions. Oxford: Oxford University Press.

van Aelst, P. (2014). Media, political agendas and public policy. In C. Reinemann (Ed.), Political communication: Handbook of communication science (pp. 231-248). Berlin: De Gruyter-Mouton.

Vliegenthart, R., Walgrave, S., Baumgartner, F. R., Bevan, S., Breunig, C., Brouard, S., . . . Tresch, A. (2016). Do the media set the parliamentary agenda? A comparative study in seven countries. European Journal of Political Research, 55(2), 283-301.

Vliegenthart, R., Walgrave, S., Wouters, R., Hutter, S., Jennings, W., Gava, R., . . . Chaques-Bonafont, L. (2016). The media as a dual mediator of the political agenda-setting effect of protest: A longitudinal study in six western European countries. Social Forces, 95(2), 837-859.

Walgrave, S., \& Vliegenthart, R. (2012). The complex agenda-setting power of protest: Demonstrations, media, parliament, government, and legislation in Belgium, 1993-2000. Mobilization, 17(2), 129-156.

Wilkes, R., Corrigall-Brown, C., \& Myers, D. J. (2010). Packaging protest: Media coverage of indigenous people's collective action. Canadian Review of Sociology, 47(4), 327-357.

Wilson, P. (2015). The misuse of the Vuong test for nonnested models to test for zero-inflation. Economics Letters, 127, 51-53.

Ylä-Anttila, T., Gronow, A., Stoddart, M. C. J., Broadbent, J., Schneider, V., \& Tindall, D. B. (2018). Climate change policy networks: Why and how to compare them across countries. Energy Research \& Social Science, 45, 258-265.

Young, N., \& Dugas, E. (2011). Representations of climate change in Canadian national print media: The banalization of global warming. Canadian Review of Sociology, 48(1), 1-22. 


\section{About the Authors}
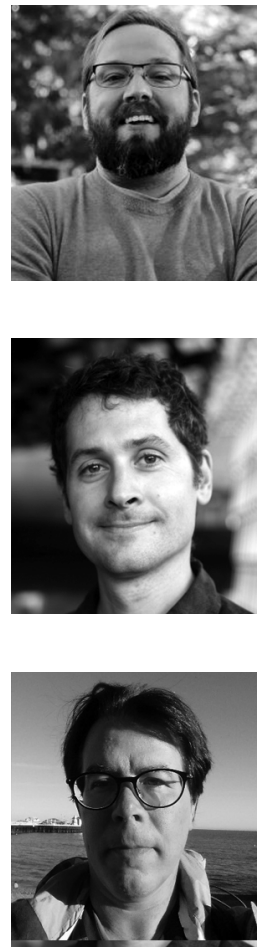

Adam C. Howe is a PhD Candidate at the University of British Columbia in Vancouver. His research interests include environmental sociology and climate change governance, social movements and activism, and computational social science. His current research uses a policy network perspective to study how social structure (social networks) and media intersect to shape social influence and climate change governance. His work most recently appears in the academic journal Sociological Perspectives, and in the edited book Protest Public Relations: Communicating Dissent and Activism.

Mark C. J. Stoddart is Professor in the Department of Sociology at Memorial University, with research interests in environmental sociology, social movements, and communications and culture. He is the author of the book Making Meaning out of Mountains: The Political Ecology of Skiing (UBC Press). His work appears in a range of sociology and interdisciplinary journals, including Global Environmental Change, Energy Research \& Social Science, Organization \& Environment, Environmental Politics, Journal of Sustainable Tourism, Environmental Communication, Mobilities, and Social Movement Studies.

David B. Tindall is a Professor in the Department of Sociology at the University of British Colombia, where he studies, and teaches about, contention over environmental issues. His recent and ongoing research examines various aspects of the environmental movement, and environmentalism in Canada, media coverage of climate change discourse and other environmental topics, climate change politics and policy networks in Canada, and public opinion about climate change and other environmental issues. His current research examines the role of social networks in fostering climate action, and compares and contrasts the roles of virtual and non-virtual social network ties. 